Hege Rangnes

Universitetet i Stavanger

Aslaug Fodstad Gourvennec

Universitetet i Stavanger

DOI: http://dx.doi.org/10.5617/adno.6282

\title{
Læreres samtale om pedagogisk bruk av flerspråklige elevers prøveresultater
}

\section{Sammendrag}

Siden begynnelsen av 2000-tallet har det vært et utdanningspolitisk ønske i Norge om å kvalitetsvurdere opplaringen i skolen, og det er i den forbindelse innført obligatoriske kartleggingsprøver og nasjonale prøver. Vi vet at lcerere er usikre på oppfølgingen av prøveresultatene. Som et ledd $i$ a styrke underveisvurderingen, har Utdanningsdirektoratet lansert digitale leringsstøttende prøver med veiledninger for mellomtrinnet. En av disse prøvene, en vokabularprøve, er særlig innrettet mot den konkrete oppfølgingen av flerspråklige elever. I denne studien undersøker vi, inspirert av et kritisk case-design, hvordan åtte lcerere forstått som deltakere med fullt medlemskap i et praksisfellesskap (Lave \& Wenger, 1991), reflekterer over flerspråklige elevers prøveresultater. Ved å anvende Breiter og Lights (2006) begreper knyttet til lareres beslutningstaking basert på data - såkalt data-driven decision making - analyserer vi hvordan lcererne i løpet av en samtale beveger seg fra å forklare elevenes resultater på vokabularprøven til å bygge på disse forklaringene når de skal ta målrettede valg om fremtidig undervisning. Studien viser at deltakerne i løpet av samtalen utvikler felles kunnskap om flerspråklige elevers oppleringsbehov som potensielt vil kunne føre til endring i praksis. Samtidig avdekker studien at lerernes nyervervede kunnskap bare delvis er forankret i elevresultatene. Studien peker mot et behov for at skolene gir rom for strukturerte samtaler om prøveresultater hvor også flerspråklige elever blir tematisert. Siktemålet for slike samtaler må vœre å skape anvendbar kunnskap basert på alle elevers prøveresultater.

Nøkkelord: pedagogisk bruk av prøver, data-driven decision making, praksisfellesskap, flerspråklige elever, akademisk vokabular 


\title{
Teachers in conversation about the use of second language learners' test results for instructional purposes
}

\begin{abstract}
Over the last two decades, the Norwegian Government has focused strongly on assessing the quality of education in schools. This focus has led to the introduction of both compulsory screening tests and national tests. Current research indicates uncertainty on the part of teachers about how to use and follow up the test results. In order to strengthen formative assessment practice and teachers' competence in using test results to guide instruction, the Norwegian Directorate for Education and Training has introduced a series of tests in digital format, with accompanying teacher manuals, for use in grades 57. One of these tests, a vocabulary test, focuses particularly on supporting second language learners' (SLLs) learning. In this study, we employ a critical case design to investigate how eight teachers, understood as full participants in a community of practice (Lave \& Wenger, 1991), engage in a collective learning process around SLLs' test results. Using Breiter and Light's (2006) concepts related to research on teachers' data-driven decision making, we analyze how these teachers during a conversation move from explaining SLLs test results from the vocabulary test, to making targeted decisions for future instruction. The analysis reveals that during the conversation, the participants develop shared knowledge about the academic needs of SLLs, which could potentially lead to instructional improvement. However, this knowledge is only partly grounded in the test results. The findings suggest that the schools make room for structured conversations about SLLs test results to guide future decisions. Further research should continue to investigate how teachers could improve their instruction based on test results.
\end{abstract}

Keywords: instructional use of tests, data-driven decision making, community of practice, second language learners, academic vocabulary 


\section{Innledning}

Norske elever har deltatt i internasjonale lesetester siden 1991, og på begynnelsen av 2000-tallet ble det også innført obligatoriske kartleggingsprøver og nasjonale prøver. Det er en utdanningspolitisk forventning om at prøveresultater skal brukes til å forbedre praksis og elevenes opplæringstilbud (Datnow, Park \& Kennedy-Lewis, 2012; Kunnskapsdepartementet, 2013). Flerspråklige elever ${ }^{1}$ presterer som gruppe lavere enn elever med norsk som morsmål/førstespråk på både de nasjonale og internasjonale lesetestene (Kjærnsli \& Jensen, 2016; Strand, Wagner \& Foldnes, 2017; Utdanningsdirektoratet, 2017), og det er derfor et særlig utdanningspolitisk ønske om å bedre opplæringstilbudet til denne elevgruppen. Stortingsmeldingen På rett vei (Kunnskapsdepartementet, 2013) pekte ut behovet for vurderingsverktøy som i større grad ga føringer for undervisning. I kjølvannet av stortingsmeldingen lanserte Utdanningsdirektoratet derfor lceringsstøttende prøver, et digitalt prøvekonsept normert for 6 . trinn som skulle være et verktøy for lærere til å gi læringsfremmende tilbakemeldinger til alle elever. Blant de læringsstøttende prøvene i lesing har en vokabularprøve et spesielt fokus på oppfølging av flerspråklige elever ${ }^{2}$, dette fordi svakt vokabular hyppig fremheves som den største utfordringen for denne elevgruppens skoleprestasjoner (Anstrom et al., 2010; Golden \& Kulbrandstad, 2007; MelbyLervåg \& Lervåg, 2011; Townsend, Filippini, Collins \& Biancarosa, 2012). Vi vet en del om læreres bruk av prøveresultater (Gannon-Slater et al., 2017; Garner, Thorne \& Horn, 2017; Gunnulfsen \& Roe, 2018; Mausethagen, Prøitz \& Skedsmo, 2018; Monsen, 2014; Seland, Vibe \& Hovdhaugen, 2013). Derimot vet vi ikke hvordan lærere forstår og bruker et prøvekonsept som både retter seg mot en spesifikk elevgruppe, og som prøver å skape en bro mellom skåre og undervisning. Målet med denne studien er derfor å undersøke læreres forståelse av flerspråklige elevers prøveresultater fra vokabularprøven, og hvordan de planlegger å bruke resultatene i oppfølgingsarbeidet.

\section{FRA PRØVERESULTATER TIL PRAKSIS}

$\AA ̊$ tolke prøveresultater og ta beslutninger om videre undervisning på bakgrunn av disse tolkningene er en prosess som er nært beslektet med velkjente handlingsmønstre i lærernes profesjonelle hverdag. Innføringen av sentralt gitte prøver bringer imidlertid noe nytt inn i denne prosessen fordi lærerne må

\footnotetext{
${ }^{1}$ Flerspråklige elever er en svært heterogen gruppe. I denne studien bruker vi betegnelsen som pedagogisk kategori (NOU 2010:7, s. 27), og avgrenser den til å gjelde elever med et annet morsmål/førstespråk enn norsk og samisk (Barne-, likestillings- og inkluderingsdepartementet, 2012, s. 49). I studien undersøker vi ikke elevenes bakgrunn, men forholder oss til lærernes forståelse av hvem disse elevene er, og hvilke opplæringsbehov de har.

${ }^{2}$ I prøvemateriellet er elevgruppen omtalt som minoritetsspråklige elever.
} 
forholde seg til prøver de selv ikke har utviklet (Mandinach, Honey, Light \& Brunner, 2008). I en amerikansk kontekst er læreres beslutningstaking basert på prøveresultater beskrevet som data-driven decision making (DDDM), der data er selve prøveresultatene. Det pekes på at lærerne må være data-literate for å kunne tolke prøveresultater og legge tolkningene til grunn for endringer av undervisningen som fremmer elevenes læring (Gummer \& Mandinach, 2015, s. 2). For at en endring av praksis skal være mulig, hevder Schildkamp og Kuiper (2010) at lærerne må se prøveresultater og undervisning i tett sammenheng. Flere har tatt til orde for at læreres forståelse og bruk av prøveresultater har størst utviklingspotensial hvis det løftes inn i lærerkollegiet og gir lærerne muligheten til å delta i målrettede samtaler med en viss struktur (Abrams, McMillan \& Wetzel, 2015; Datnow et al., 2012; Garner et al., 2017; Marsh, Bertrand \& Huguet, 2015). I tråd med dette viser Junges (2012) studie at det er lite læring i læreres kollegasamtaler uten noe form for styring. Samtidig påpeker Datnow og Hubbard (2016, s. 23) at det er for lite fokus på utvikling av læreres undervisningskompetanse som en del av DDDM-prosessen. En konsekvens er at læreres oppfølging gjerne består av å gjøre mer av det samme (reteaching) (Datnow et al., 2012; Garner et al., 2017), eller av skisserte tiltak som økt fokus på lesing (Monsen, 2014, s. 183).

Selv om flerspråklige elever som gruppe skårer lavere på lesetester enn elever som har morsmålet/førstespråket som opplæringsspråk, er det også signifikante resultatforskjeller mellom flerspråklige elever som er født i landet og de som selv har innvandret til landet (Kjærnsli \& Jensen, 2016; Utdanningsdirektoratet, 2017). Et sentralt spørsmål i møte med slike testresultater er hvorvidt det primært er fagkunnskaper eller elevens språkferdigheter som testes (Bailey \& Butler, 2003), og vi vet at flerspråklige elevers læringsutbytte - målt i leseforståelse - er sterkt relatert til ordforrådet på andrespråket (Melby-Lervåg \& Lervåg, 2011). Norske metaforer (Golden, 2006; Kulbrandstad, 1998), sammensatte ord (Golden \& Kulbrandstad, 2007), morfologisk komplekse ord og flerbetydningsord (Vadasy \& Nelson, 2012) er utfordrende for flerspråklige elever. Det er likevel særlig det akademiske vokabularet som preger fagtekster allerede fra barneskolen som blir fremholdt som en hindring for flerspråklige elevers tekstforståelse (Anstrom et al., 2010; Baker et al., 2014; Schuth, Köhne \& Weinert, 2017). Det skilles mellom fagspesifikke akademiske ord og generelle akademiske ord som går på tvers av fag (Nagy \& Townsend, 2012). I tillegg til de fagspesifikke ordene, er særlig det generelle akademiske vokabularet i fagtekster utfordrende for flerspråklige elever (Baker et al., 2014; Haag, Heppt, Stanat, Kuhl \& Pant, 2013; Townsend et al., 2012). Disse ordene blir det ofte tatt for gitt at elevene kan (Snow, 2010). For å skaffe et informativt grunnlag for å iverksette tiltak, er det derfor viktig å kartlegge denne elevgruppens ferdigheter i opplæringsspråket (Melby-Lervåg og Lervåg, 2011), særlig knyttet til akademisk vokabular (Bailey og Butler, 2003). 
Selv om det har blitt brukt store ressurser på å utvikle solide psykometriske prøver til bruk i skolen, vet vi at lærerne er usikre på hvordan de skal anvende resultatene i undervisningen (Datnow \& Hubbart, 2016; Gannon-Slater et al., 2017; Gunnulfsen \& Roe, 2018; Monsen, 2014; Seland et al., 2013). Mausethagen et al. (2018) viser til at læreres oppfølging av prøveresultater er rettet inn mot å forbedre prøveresultatene, og tidligere forskning tyder på at lærere i liten grad bruker elevresultater til å endre egen undervisning (GannonSlater et al., 2017; Garner et al., 2017; Schildkamp \& Kuiper, 2010). Videre påpeker både Gannon-Slater et al. (2017, s. 371-372) og Garner et al. (2017, s. 420) at lærere i liten grad utnytter det potensialet som ligger i formativ vurdering av flerspråklige elever, og at det sosiale utjevningsperspektivet i liten grad er tilstede i lærernes refleksjoner over prøveresultater. I følge Mandinach et al. (2008, s. 17) ser lærere lite etter mønster i resultatene på gruppenivå. I en norsk kontekst påpekes behovet for mer forskning på underveisvurdering av flerspråklige elever (Randen, 2016, s. 365).

\section{TEORETISK FORANKRING}

Studien er forankret i Lave og Wengers (1991) teoretiske begrep praksisfellesskap (communities of practice). I slike fellesskap utvikles forståelse og kunnskap gjennom interaksjon med andre (Lave \& Wenger, 1991, s. 94). Praksisen er ikke stabil, men hele tiden gjenstand for forhandling deltakerne imellom. Deres deltakelse (participation) i praksisen og tingliggjøring (reification) av praksisen sikrer både kontinuitet og diskontinuitet (Wenger, 1998). Teorien springer ut av observasjoner av hvordan læring foregår ved deltakelse på innsiden av fellesskapet - selv for nykommerne i praksisen gjennom legitim perifer deltakelse. Når nykommerne beveger seg innover i praksisen, beveger de seg mot fullt medlemskap (full membership). Et fullt medlemskap er knyttet til deltakelse og identitet snarere enn oppnåelse av et spesifikt ferdighetsnivå eller at man er kommet til praksisens endestasjon; også slike medlemmer er i stadig bevegelse innenfor praksisen. I et praksisfellesskap bestående av lærere, kan vi se for oss at den daglige forhandlingen om praksisen foregår blant annet gjennom deltakelse i samtaler mellom lærere, med ledelsen og i selve undervisningen. Tingliggjøringen av praksisen vil vi blant annet finne i artefakter som styringsdokumenter, lærebøker, ukeplaner, undervisningsopplegg og sentralt gitte prøver.

Flere utdanningsforskere har anvendt og videreutviklet DDDM-modeller med formål om å observere lærernes prosess med å forstå og bruke prøveresultater pedagogisk (Breiter \& Light, 2006; Coburn \& Turner, 2011). I denne studien anvendes Breiter og Lights (2006) modell, utviklet fra Ackoffs (1989) rammeverk for management-utvikling, for å undersøke læreres bruk av prøveresultater. Breiter og Light (2006) deler DDDM-prosessen i tre faser. Den 
første fasen omhandler data, som eksisterer «in a raw state. They do not have a meaning in and of itself. [...] Whether or not data become information depends on the understanding of the person looking at the data», hevder Breiter og Light (2006, s. 210). Mandinach et al. (2008) utdyper datafasen, og peker på at lærerne i denne fasen prøver å organisere resultatene for å forstå dem, for eksempel ved å se etter mønstre. Der lærerne tradisjonelt har samlet inn og organisert prøveresultater, gjør ofte digitale prøveplattformer mye av denne jobben nå (Light, Wexler \& Heinze, 2004, s. 13). Under den andre fasen, informasjon, gis data mening

when connected to a context. [Information] is data used to comprehend and organize our environment unveiling an understanding of relations between data and context. Alone, however, it does not carry any implications for future action (Breiter \& Light, 2006, s. 210).

Den tredje fasen, kunnskap, foregår i to steg:

Knowledge is created through a sequential process. In relation to test information, the teacher's ability to see connections between students' scores in different item-skills analysis and classroom instruction, and then act on them, represents knowledge (Breiter \& Light, 2006, s. 210).

\section{DENNE STUDIEN}

I denne studien undersøker vi hvordan lærere forstår og planlegger å bruke et nytt prøvekonsept særlig innrettet mot flerspråklige elever som en bro mellom skåre og undervisning. Utdanningsdirektoratet lanserte i 2016 den læringsstøttende vokabularprøven for mellomtrinnet for å imøtekomme behovet for pedagogisk bruk av prøveresultater for flerspråklige elever. Denne prøven måler elevenes kunnskaper om generelle akademiske ord. Som en utvidet del av denne kunnskapen, måles også kunnskap om metaforer, flerordsuttrykk og morfologisk komplekse ord. Ordkunnskapen blir målt blant annet gjennom ulike dimensjoner som synonymer, flerbetydningsord, kategorisering og antonymer. Alle ordene er hentet fra læreverk i ulike fag på 6. trinn, eller fra to tekster ment for aldersgruppen: Fordel å vcere tokulturell (Youmans, 2013) og Jeg vil bli statsminister! (Sandvik-Ebbing, Abdalla \& Skedsmo, 2014). ${ }^{3}$ Med unntak av kategoriserings- og antonymoppgavene, er alle ordene i prøven kontekstualisert i ulik grad - fra å inngå i en setning til en hel tekst. Oppgavene er stort sett flervalgsoppgaver. Med vokabularprøven følger en omfattende veiledning med klasseromsnære eksempler på hvordan lærere kan invitere til deltakende samtaler om ord i en kontekst, og på hvordan enkeltelever og/eller smågrupper

\footnotetext{
${ }^{3}$ I prøven er tekstene lettere bearbeidet.
} 
av elever kan følges opp i ordinær undervisning. Veiledningen er utformet med intensjon om å fasilitere en læringsstøttende bruk av prøveresultater både på kort og lengre sikt. Elevresultatene vises i Utdanningsdirektoratets prøveadministrasjonssystem (PAS), hvor de allerede er delvis systematisert i tre ulike resultatvisninger; 1) på individ/item/dimensjonsnivå, 2) individ/mestringsnivå, og 3) løsningsprosent på itemnivå i klassen versus nasjonalt nivå. Det er utviklet tre mestringsnivå, hvor nivå en er det laveste nivået og nivå tre er det høyeste. Prøvens hensikt er å gi informasjon om elever med et svakt akademisk vokabular, og den er derfor forholdsvis enkel. Ved normering presterte halvparten av alle elevene, uavhengig av morsmål, på nivå tre.

I denne studien undersøker vi hvordan lærere forstår og planlegger å bruke resultatene fra vokabularprøven. Ved å studere en situasjon hvor mye er lagt til rette for lærernes refleksjon over prøveresultater og anvendelse av dem til fremtidig pedagogisk bruk, vil denne studien bidra til kunnskap om potensialet for pedagogisk bruk av prøveresultater for flerspråklige elever i en norsk kontekst. I studien vil vi besvare følgende forskningsspørsmål:

1. Hvordan forklarer åtte lærere i en samtale sine flerspråklige elevers resultater på en vokabularprøve?

2. Hvordan bygger lærerne på disse forklaringene når de omtaler fremtidig vokabularundervisning for flerspråklige elever?

\section{METODEVALG}

\section{Design}

For å undersøke lærernes muligheter for å gjennomføre en refleksjonsprosess over prøveresultater som kan føre til endringer i fremtidig praksis, inviterte vi lærere til et fokusgruppeintervju. Ifølge Kvale og Brinkmann (2015, s. 179-180) er fokusgruppeintervjuets hensikt å få frem ulike synspunkter, og det er velegnet til eksplorative undersøkelser.

I forskningsspørsmålene omtaler vi intervjuet som en samtale fordi fokusgruppeintervjuet hadde enkelte trekk ved seg som er nært beslektet med samtalen; deltakerne besvarte spørsmål, men ble også gitt rom til å komme med innspill på hverandres svar og diskutere hverandres innspill. Disse trekkene ble understreket ved innledningen til intervjuet og etterstrebet i gjennomføringen. Samtidig hadde intervjuet noen trekk som understreket deltakernes ulike roller i situasjonen; fasilitatoren representerte et annet fellesskap hjemmehørende i akademia, hun hadde forberedt sine spørsmål og hadde et overordnet ansvar for samtalens gang. I form minnet intervjuet om den type målrettede og strukturerte samtaler som inviterer til refleksjon over prøveresultater og som fremheves som betydningsfull for lærernes pedagogiske bruk av disse (Abrams et al., 2015; 
Datnow et al., 2012; Garner et al., 2017; Marsh et al., 2015). Lærerne i denne studien fikk dermed støtte i refleksjonsprosessen over prøveresultatene både gjennom prøvens veiledningsmateriell og samtalen de deltok i. Både vokabularprøven, prøveresultatene, veiledningen og forskernes tilstedeværelse og ytringer representerte artefakter og deltakelse som trådte inn i forhandlingen om hva praksisen er og kan være - og som dermed kunne rokke ved lærernes forståelse av praksisen og deres egen rolle i den. Begge artikkelforfatterne var til stede under intervjuet. Førsteforfatteren fungerte som fasilitator i samtalen, mens andreforfatteren primært var aktivt lyttende og kun stilte enkelte oppfølgingsspørsmål.

Lærernes samtale forstås i denne studien som et kritisk case i kraft av både utvalget og intervjusituasjonen. Et slikt case egner seg for å undersøke om en antakelse kan gjøre seg gjeldende i spesielle tilfeller. I denne studien er tilnærmingen $\mathrm{i}$ tråd med det kritiske casets negativt formulerte generaliseringskarakteristikk: "If this is not valid for this case, then it is not valid for any (or only few) cases" (Flyvbjerg, 2006, s. 230). Dersom lærernes refleksjonsprosess i denne samtalen ikke pekte mot endringer i fremtidig vokabularundervisning av flerspråklige elever, er det rimelig å anta at samtaler om prøveresultater mellom andre lærere i andre situasjoner heller ikke gjør det.

\section{Utvalg}

I denne studien forstår vi lærere på mellomtrinnet som et praksisfellesskap, og i samtalen deltok åtte representanter fra dette fellesskapet. Med Lave og Wenger (1991) forstår vi disse lærerne som innehavere av fullt medlemskap i praksisfellesskapet, og som både erfarne, kompetente, engasjerte og særlig forberedt til samtalen de her skal inn i. Ved å si seg villige til å delta på intervjuet, sa lærerne seg samtidig villige til å gjennomføre vokabularprøven og et par eksempel fra prøvens veiledning i egen klasse. For å få et strategisk utvalg (purposeful sample) (Creswell, 2013, s. 155), var kriteriene for lærernes deltakelse i samtalen at de hadde erfaring med undervisning for flerspråklige elever i ordinær undervisning. Lærerne hadde 5 - 25 års undervisningspraksis, hvorav 4 - 20 års erfaring fra skoler i områder med relativt høy andel innvandrere $^{4}$. Tre av lærerne hadde videreutdannelse i lesing, to av dem tok videreutdannelse som lærerspesialister, og en av lærerne hadde master i spesialpedagogikk. Syv av lærerne var kontaktlærere på mellomtrinnet.

\section{Organisering av samtalen}

Samtalen fant sted våren 2018 i universitetets lokaler, og den varte i to timer. Intervjuet var semistrukturert, og for hvert av hovedspørsmålene fikk alle lærerne uttale seg før ordet ble gitt fritt. Det var stort rom for lærernes diskusjoner seg imellom. Spørsmålene i samtalen pekte mot ulike deler av

\footnotetext{
${ }^{4}$ Informasjon hentet fra kommunenes levekårsundersøkelse.
} 
refleksjonsprosessen knyttet til data, informasjon og kunnskap. Først mot gjennomføringen av prøven, uthentingen av og lesingen av elevenes prøveresultater, deretter mot forklaringer av prøveresultatene til de flerspråklige elevene og utprøvingen av eksemplene fra veiledningen. Til slutt var spørsmålene rettet mot videre undervisning for å støtte flerspråklige elevers utvikling av generelt akademisk vokabular.

\section{Analytisk tilnærming til materialet}

Lærernes ytringer i samtalen utgjør studiens datamateriale. Det ble gjort lydopptak av samtalen, og opptaket ble deretter transkribert ${ }^{5}$ og anonymisert. Hver av intervjuets $496^{6}$ ytringer ble nummerert. Transkripsjonen ble importert til NVivo11 for koding og benyttet som primærkilde i analysearbeidet. Alle navn i artikkelen er pseudonymer.

I analysene av samtalen undersøkes lærernes forståelse slik den kommer til uttrykk diskursivt (Gee, 2011), og den enkelte språklige ytring forstås i lys av samtalen som helhet. I disse ytringene forholder lærerne seg aktivt både til prøven, deres egne elevers prøveresultat, veiledningen, tidligere undervisning og tanker om fremtidig undervisning, til spørsmålene de får fra fasilitatoren og hverandres ytringer.

I vårt kodingsarbeid ble data, informasjon og kunnskap benyttet som organisatoriske (organizational) kategorier (Maxwell, 2005, s. 107). De tre fasene i DDDM-prosessen fungerte dermed som struktur og forståelsesramme for den videre eksplorative tilnærmingen til datamaterialet. For hver av de organisatoriske kategoriene laget vi et hierarki av underkategorier - der noen av kategoriene vokste frem fra informantens ytringer (emic), mens andre var forskernes teoretiske kategorier (etic) (Maxwell, 2008, s. 238). Vi utviklet underkategorier knyttet til data om lærernes forståelse av hva resultatene viste og hvordan de syntes det var å finne resultatvisningene i PAS. Under informasjon utviklet vi to underkategorier koblet til hvordan lærerne forklarte elevenes prøveresultater ved hjelp av i) elevegenskaper, for eksempel elevenes forutsetninger, atferd og strategier, og ii) prøvekonseptet slik lærerne forstod og beskrev prøven og oppgavene. Under kategorien kunnskap laget vi to underkategorier som beskriver de to stegene i kunnskapsfasen. Den ene, tidligere vokabularundervisning, beskriver lærernes diskursive forståelse av koblingen mellom tidligere vokabularundervisning og elevenes resultater. Den andre, fremtidig vokabularundervisning, favner lærernes omtaler av hvilke konsekvenser dette burde få for flerspråklige elever i fremtidig vokabularundervisning. Kodehierarkiet ble ytterligere utvidet. For eksempel ble det under prøvekonseptet etablert en kategori kalt dimensjoner for lærernes

\footnotetext{
${ }^{5}$ I transkriberingen ble det brukt en forenklet utgave av Jeffersons transkripsjonsnøkkel (Atkinson \& Heritage, 1999). I denne teksten vil leseren møte følgende transkripsjonstegn: (( )) - brukt for å markere handlinger.

${ }^{6}$ En av informantene ankom intervjuet noe senere, og fikk mulighet til å uttale seg om de innledende spørsmålene etter at hovedintervjuet var ferdig.
} 
ytringer om de ulike delprøvene som målte dimensjoner av ord (for eksempel synonymer og flerbetydningsord). Videre ble kategorien akademisk vokabular utviklet under prøvekonseptet for å beskrive lærernes forståelse av hvilke ord som var vanskelige i prøven. Et siste eksempel er kategorien tekster under kategorien fremtidig vokabularundervisning.

\section{RESULTATER}

Helt sentralt for at prøveresultatene skal kunne utgjøre et meningsfullt grunnlag for endringer av praksis, er det at hovedfasene i refleksjonsprosessen - data, informasjon og kunnskap - bygger på hverandre. Denne prosessen og hvordan de ulike fasene bygger på hverandre er synliggjort i studiens to forskningsspørsmål; hvordan lærerne forklarer resultatene, og hvordan de bygger på resultatene i fremtidige valg i undervisningen. Selv om spørsmålene fra fasilitatoren pekte mot hele DDDM-prosessen, var det mest fremtredende i datamaterialet lærernes forklaringer av elevenes prøveresultater hvor de knyttet resultatene til elevegenskaper (informasjonsfasen), prøvekonseptet (informasjonsfasen) og egen tidligere vokabularundervisning (første steg i kunnskapsfasen). Disse forklaringene ligger til grunn for strukturen i presentasjonen av resultatene. For å tydeliggjøre hvordan de tre fasene data, informasjon og kunnskap bygger på hverandre, vil vi under hver forklaring presentere lærernes refleksjonsprosess i lys av hele DDDM-prosessen; hvordan disse er forankret i lærernes forståelse av data som er hentet i den digitale prøvebanken (datafasen), og hvordan de peker fremover mot en mulig endring $\mathrm{i}$ fremtidig praksis (kunnskapsfasen).

\section{Elevegenskaper}

Lærerne forklarte prøveresultater ut fra elevegenskaper, for eksempel ved at mange elever ble overveldet av alle de vanskelige ordene og uttrykkene som de måtte forholde seg til alene på prøven, eller ved at mange ga opp, ikke minst da de kom til tekstene: «Det var veldig mange vanskelige ord i teksten for mine elever. De hadde vansker med å forstå hva de i det hele tatt leste» Sissel (216 ${ }^{7}$. Lærerne uttrykte videre at elevenes alder, hvorvidt de var stresset, vimsete, unøyaktige, arbeidet for raskt, ikke husket noe fra tidligere undervisning eller ikke forstod oppgaveordlyden i prøven, hadde betydning for resultatene. Resultatene ble også beskrevet i lys av elevenes strategier: «De koblet ikke spørsmålene til tekst. De tenkte på at dette finner jeg ut av meg selv» (Anette, 214). Videre viste lærerne ofte til elever med relativt store vansker, uavhengig av morsmål: «Jeg gikk gjennom [prøven] med en som hadde dysleksi, og det var mye gjetting, merket jeg» (Sissel, 45).

\footnotetext{
${ }^{7}$ Tallet viser til ytringens nummer i intervjuet.
} 
Lærerne rapporterte at flerspråklige elever fordelte seg på alle de tre mestringsnivåene i prøven. Tre av lærerne hadde klasser hvor alle de flerspråklige elevene havnet på nivå 1 , mens to av lærerne uttrykte overraskelse over at det ikke var de flerspråklige elevene som presterte svakest. Tre av lærerne var overrasket over at de flerspråklige presterte bedre enn forventet. Ingunn, Sissel og Anette lot seg overraske av et gap mellom den ordkunnskapen de trodde elevene hadde, og det prøveresultatene viste. Sissel uttrykte det slik:

Det som kanskje kom som et lite sjokk for meg, er jo at noen flerspråklige kan virke veldig flinke av og til, så selv om du er obs på det, så glemmer du [det] kanskje litt. [...] Det var ei som på en måte havnet på nivå 1, og så kjente jeg etterpå: Oi, nå må vi følge litt med (Sissel, 92).

Her ser vi en bevegelse fra at læreren ble kjent med og overrasket over en elevs resultat til et eksplisitt uttrykt behov for å være på vakt. Denne oppmerksomheten innebar en bevegelse mot kunnskapsfasen, men foreløpig ble det ikke konkretisert hva årvåkenheten kunne bestå av.

I samtalen refererte lærerne hovedsakelig til elevenes resultater på mestringsnivå. Der Sara (50) så ut til å forstå dette som den mest informative resultatvisningen, sa Tone (51) at de ikke har "fått tid til" å gjøre seg kjent med de andre visningene. Noen av lærerne var oppmerksomme på ulike mønstre i de flerspråklige elevenes prøveresultater på dimensjonsnivå. For eksempel viste Bente (103) til at de flerspråklige elevene skåret svakt på synonymer. Ingen av lærerne viste til mønstre eller tolkning av elevresultater på itemnivå.

\section{Prøvekonseptet}

Lærerne forklarte resultatene ved å vise til trekk ved selve prøven. De opplevde prøven generelt som vanskelig for elevene: «Veldig mye var veldig vanskelig språk» (Bente, 35). Ulike dimensjoner ble også beskrevet som utfordrende: «Den sortering $i$ kategorier var vanskelig for dem. Og, ja, ord med flere betydninger [...] og ord som betyr det motsatte» (Jane, 94). Strukturen i prøven ble beskrevet som krevende for mange elever: «Men det at det er mye tekst langt uti, språket er såpass avansert. Såpass like setninger at du må jammen meg ha hodet klart for liksom å se forskjell på, ikke sant» (Gerd, 189). De to tekstene i prøven ble også vurdert som vanskelige av lærerne. De koblet derimot ikke deres bekymringer for vanskegrad til informasjon i veiledningen, hvor mestringsnivåene generelt og vanskegrad på den enkelte oppgaven kommenteres.

Sissel var den første som nevnte at prøven utfordrer lærernes vurderinger av elevenes vokabular: «Så der kjente jeg det var godt å få en test for å sjekke litt opp på sånne tekster som du tror at de får med seg alt, og så vet de ikke sånne ord som du tror de kan» (Sissel, 92). Gerd (126) antydet at lærere ikke er helt klar over hvordan tekster er preget av akademisk språk, men at prøven og veiledningen bidrar til å synliggjøre hvilke ord som kan være utfordrende for 
blant andre flerspråklige elever. Lærernes refleksjoner om hva slags type ord de flerspråklige elevene trenger å undervises i og eksponeres for, utviklet seg i løpet av samtalen:

Tone: $\quad$ Ja, og så det med å plukke ord. Hvilke ord skal vi plukke? Det er jo en hel vitenskap ((flere bekrefter)).

Sara: $\quad$ Vi [må] kanskje ta noen andre ord som kan brukes på tvers av tema.

$[\ldots]$

Jane: $\quad$ Sånn som du sier, akademiske [ord] eller sånne [ord] for livet deres, for en del av de fagspesifikke ordene er jo veldig spesielle. Altså sånne som de aldri, eller i alle fall sjelden får bruk for. [...] Jeg kan jo velge et annet ord da [enn fagspesifikke], sånn som er mer sånn som de får bruk for i livet.

$[\ldots]$

Bente: $\quad$ Det bare slo meg - ord du får bruk for i livet ((latter fra alle)). Vi holdt på med en tekst i dag, og det viste seg at det var veldig mange som ikke hadde idé om hva det betydde at denne bestefaren sovnet inn.

Ingunn: $\quad$ Når du snakker om det der med fagspesifikke, så tror jeg [...] at vi har så mye av det der fagspesifikke. De ordene [...] som du kan bruke i alle sammenhenger, de tar vi for gitt at de skal kunne. [...] Det er de ordene vi må bruke mer tid på. For [ordene] har [elevene] bruk for hele tiden. Når du snakker kjemi, så er det jo bare i kjemitimene, men disse ordene kan de bruke, ja, hele livet, alltid, uansett hva de skal jobbe med.

Det er sånn aha.

(275-314)

I disse oppdagelsene koblet lærerne implisitt sammen informasjon om elevegenskaper - at flere skåret lavt på prøven - med deres kunnskap om hvilke ord elevene trenger å lære. Selv om de her ikke eksplisitt kom med forslag til hva oppdagelsen kan føre til, aner vi spiren til ny erkjennelse og et ønske om endring. De beveget seg dermed i retning av kunnskapsfasen og pekte fremover mot en mulig endring av egen undervisningspraksis.

Oppdagelsen førte lærerne videre i en refleksjon over elevenes muligheter til å eksponeres for og utvikle et akademisk vokabular. Sara viste til at det språket enkelte elever møter hjemme, er av en annen karakter enn det språket elevene møter i skolen:

Jeg har bare tenkt litt på hvordan de snakker hjemme da. Det har bare slått meg, for det er en som har skåret veldig svakt. [...] Ja, de har et enkelt språk da, og bruker ikke akademiske ord når [moren] forklarer ting og hva de snakker om (Sara, 168-172).

Bente problematiserte spesielt situasjonen til flerspråklige elever som bruker kun morsmålet/førstespråket hjemme og i sosiale sammenhenger utenom skolen: «Så blir det bare skolelærdom, de ordene som vi skal liksom putte inn i stedet for det naturlige språket de ville hatt hvis det var masse norske venner» (Bente, 176). Ingunn bygget videre på Bentes utsagn og la til at «når hverdagsspråket 
deres er et annet språk, så har de jo enda mer ord som de ikke kan, sant, så de akademiske ordene er jo utrolig vanskelige for dem» (Ingunn, 180).

Utviklingen i samtalesekvensene over kan tyde på at lærerne - gjennom å forklare elevenes resultater med trekk fra prøven og elevenes forutsetninger, veiledningen og lærernes forkunnskaper - la grunnen for en gryende innsikt om at akademisk vokabular kan forstås på ulike nivå. Lærerne beskrev en undervisning der fagspesifikke ord ofte forklares og vies oppmerksomhet i undervisningen, men i løpet av samtalen ser vi en gryende forståelse for at de generelle akademiske ordene også er viktige for flerspråklige elevers tekstforståelse. Tones ytring om at det var vanskelig å velge hvilke ord en skulle jobbe med, kan tyde på at lærerne hadde en uklar forståelse av hvilke ord som er generelle akademiske. Under samtalen søkte de i liten grad oppklaring i dette i prøven eller veiledningen.

\section{Vokabularundervisning}

Lærerne forklarte også prøveresultater ved å koble dem til egen vokabularundervisning. Tanken om at flere flerspråklige elever kanskje ikke har muligheten til å møte det akademiske vokabularet i hjemmet, kan ligge til grunn for lærernes kritiske blikk på egen undervisning. De undret seg blant annet over i hvilken grad elevene faktisk møter det akademiske vokabularet i skolen: «Jeg vet ikke om det er litt på sidelinja, men vi snakket om at vi forenkler ord så mye. [...] At vi egentlig skal bruke sånne akademiske ord» (Tone, 118 og 120).

Tones kommentar startet en bevegelse i lærernes samtale inn i kunnskapsfasen, i og med hennes oppmerksomhet om trekk ved egen undervisning som mulig forklaring på enkelte elevers svake prøveresultater. Flere av lærerne reflekterte rundt det faktum at på tross av at de viet mye oppmerksomhet til ord i undervisningen, viste resultatene at mange av elevene likevel hadde et lite vokabular. Ingunn uttrykte det slik:

Jeg ble litt overrasket, for vi har følt vi har jobbet så mye med akkurat tekst og ordene i teksten, men så er det nok det, at det blir mye det der med å forklare. At vi som lærere står og forklarer, men går ikke inn i ordene, for at ungene skal klare selv å finne ut (Ingunn, 259).

Dette ledet til en samtalesekvens om hvorvidt elevene faktisk lærte ordene slik undervisningspraksisen har vært:

Vi forklarer kanskje et ord inne i en tekst, og de kan forstå fortellingen, men de får ikke lært det på den måten at de klarer å bruke det selv etterpå, at det blir en del av dem. Så det ser i alle fall jeg på som noe jeg må jobbe på en annen måte for å lære dem de ordene de får bruk for senere (Tone, 275).

Da lærerne snakket om hvordan de kunne arbeide med ord, var alle enige om at de måtte fokusere mer på ord i undervisningen. Sissel sa: «Jeg tenkte jo når jeg 
så resultatene, at, oi, jeg må tilbake til å snakke om hva begrepene faktisk betyr» (Sissel, 271), og Jane viste til at «vi må ha enda mer fokus på ord» (Jane, 283). Flere viste til at de ønsket å bruke veiledningen. Fem av lærerne påpekte at de måtte jobbe mer med dimensjoner som synonym og antonym, gjerne ved bruk av ordkart. Anette, Ingunn og Bente fremhevet at veiledningen ga innspill til arbeid med morfologi, og Bente sa det slik:

Men jeg må jo tilstå at akkurat den tilnærmingen til faktisk å vise forstavelser, ikke sant, ja, altså at dette faktisk har en egen mening. Mis- har en egen mening. [...] Der har jeg ikke vært god nok til å komme på det (Bente, 251).

Anette løftet frem at veiledningen hadde gitt innspill til hvordan en kunne bruke tekstens sammenheng for å finne ut hva et ord betyr:

Og der ser jeg at jeg er veldig flink til å stå foran klassen og forklare. Det der begrepet betyr sånn, det betyr sånn i stedet for å gå inn i teksten og jobbe med hvordan vi kan finne det ut. Hvordan kan vi se på sammenhengen for å finne ut hva ordene betyr? Så det har vi jobbet mye med i etterkant [av prøvegjennomføringen] (Anette, 253).

Anette begrunnet valg av eksempler fra veiledningen med at det skulle kunne følges opp i hel klasse. Ingen av lærerne ga uttrykk for at de brukte veiledningens eksempler på å utnytte tiden til å arbeide tettere med enkeltelever/grupper når klassen hadde parsamtaler. Generelt beskrev lærerne veiledningen som god, men de fryktet at den var så omfattende at mange lærere ikke ville ha tid til å sette seg inn i den. To av lærerne viste imidlertid til det at veiledningen kan brukes i et langsiktig perspektiv. Bente uttrykte det slik:

Jeg føler jeg har akkurat begynt med oppfølgingsarbeidet. [...] Altså de har jo ikke lært disse ordene på en uke. Altså det er jo mange, mange ting her å jobbe med over kjempelang tid. Og ikke minst, om det ikke er akkurat disse ordene, så er det ideer til hvordan du kan jobbe med ordene, som en kan bruke over lang tid (Bente, 405 og 409).

Det begynnende kritiske blikket på egen vokabularundervisning ble i løpet av samtalen utvidet til å gjelde mer generelle pedagogiske valg i undervisningen:

Altså, jeg satt og tenkte, lar [elevene] være å tenke? Altså, støtter vi så mye noen ganger, at de får så mange forklaringer, at de vet at alt som er viktig her, det kommer hun til å forklare på forhånd likevel, ikke sant, så jeg trenger egentlig ikke tenke (Bente, 123).

Sissel bygget videre på tanken om at lærerne sidestiller tilpasset opplæring med en forenklet undervisning: 
Ja, når de sier det der med at å tilpasse så mye som vi gjør. Det tror jeg vi gjør mye. At vi tilpasser det ned, sånn som [Gerd] sa, sant, så det kan være derfor at de ikke forstår de vanskeligste ordene, fordi de ikke vet hvordan (Sissel, 128).

Anette pekte i tråd med dette på at «jeg merker at jeg ofte gir dem litt enklere tekster, at jeg skåner dem litt for de vanskelige tekstene» (Anette, 423). Gerd forsvarte imidlertid forenklingene i undervisningen med at «vi vil jo at alle skal forstå» (Gerd, 126).

Tanken om å arbeide mer i dybden med tekstene, var også Ingunn opptatt av:

Vi rusher litt for fort i tekstene vi jobber med. Kanskje må vi tenke mer gjennom hvilke tekster vi bruker, og så jobbe med denne måten ((peker på veiledningen)) med tekster. For det er jo da det vider seg ut for [elevene] (Ingunn, 415).

Implisitt i disse ytringene ligger en forståelse av at måten en arbeider med ord og tekster på kanskje ikke løfter elevene med svakest vokabular, og at de dermed ikke var rustet til å møte forventningene prøven la opp til. Lærerens avgjørende rolle for elevenes læring ble eksplisitt støttet av Ingunns utsagn: «Jeg tror det handler jo som regel om oss selv i klassen» (Ingunn, 371).

Flere av lærerne nevnte at det var altfor lite tid i hverdagen til å reflektere dem imellom, og mot slutten av samtalen uttrykte lærerne at de satte pris på å delta i samtalen. Ingunn formulerte seg slik:

Jeg tror [det å delta i samtalen] er veldig lærerikt for oss da. Det å få være med på sånt. Det er jo det som er motivasjonen for å være med på sånne ting, at du får noen tips og blir litt klokere selv da. Og det gagner jo elevene etter hvert. [...] [Det] at vi er med på dette, tror jeg gagner [...] enda mer enn veiledningen (Ingunn, 384 og 386).

\section{DISKUSJON}

I denne studien har vi undersøkt hvordan åtte lærere - forstått som deltakere med fullt medlemskap i et praksisfellesskap av mellomtrinnlærere - beveget seg gjennom en forståelsesprosess innfor rammene av en samtale. Vi har forsøkt å besvare hvordan lærerne forklarte flerspråklige elevers prøveresultater, og hvordan de bygget på disse forklaringene da de omtalte fremtidig vokabularundervisning. For at en slik refleksjonsprosess skal kunne skje, er det nødvendig at de ulike hovedfasene i prosessen bygger på hverandre. I det følgende vil vi diskutere fire hovedfunn.

Det første hovedfunnet er i tråd med internasjonal forskning (Abrams et al., 2015; Datnow et al., 2012; Garner et al., 2017; Marsh et al., 2015), nemlig at den strukturerte samtalen fungerer som en arena for lærernes kunnskapsutvikling. I samtalen fungerte prøven, resultatene, veiledningen og forfatternes spørsmål som artefakter og deltakelse i hendelsen som inviterte til 
eksplisitt forhandling mellom lærerne om eksisterende og fremtidig praksis. Det vil si en forhandling som i større og mindre grad rokker ved deres tidligere forståelse. I løpet av samtalen utvikler lærerne en forståelse for at vokabularkunnskapens rolle for flerspråklige elevers forståelse av fagtekster ikke er begrenset til å gjelde fagspesifikt vokabular, men at kunnskap om generelle akademiske ord også er viktig for elevgruppen. Vi ser at lærerne kobler nyervervet kunnskap, spesielt om generelt akademisk vokabular, til hvorfor flere elever skårer svakt på vokabularprøven. Det er særlig i lærernes oppdagelser av at prøven tester elevene i ord det er forventet at de skal kunne, og i deres kobling mellom dette og hvilke forutsetninger elevene har for å lære denne type ord, at vi ser lærernes bevegelse mot kunnskapsfasen. Resonnementet om at mange elever ikke har muligheten til å utvikle et akademisk vokabular i hjemmet, leder til en forståelse av skolens ansvar i så måte. Samtlige lærere viser imidlertid frustrasjon over at det er vanskelig å identifisere hva som er generelle akademiske ord. En slik usikkerhet gjør det utfordrende for lærerne å identifisere generelle akademiske ord i tekster det arbeides med i klassen. Fagspesifikke ord vil i større grad være enkle å plukke ut fra en tekst, men lærernes kunnskap om generelle akademiske ord er en nødvendig forutsetning for å kunne møte blant andre flerspråklige elevers opplæringsbehov.

Det andre hovedfunnet står i kontrast til forskning som viser at lærere i liten grad knytter resultatene til egen undervisning (Gannon-Slater et al., 2017; Garner et al., 2017; Schildkamp \& Kuiper, 2010). I denne studien blir lærerne bevisste på skolens ansvar for utvikling av elevenes akademiske vokabular, og det fører til et kritisk blikk på egen undervisning. De beskriver egen undervisning som forenklende i språk og tekstvalg, og de peker på dette som en mulig årsak til elevenes resultater. Denne forklaringen utvikles i løpet av samtalen, gjennom lærernes eksplisitte og implisitte forhandlinger om praksisen - slik den er og burde være. Det er for eksempel interessant at Anette reflekterer rundt at hun har pleid å gi flerspråklige elever enklere tekster for å skåne dem. Lærernes refleksjoner over mulige sammenhenger mellom egen undervisning og elevenes resultater, kan gi grobunn for å bruke prøveresultatene til å endre praksis (Schildkamp \& Kuiper, 2010).

Et tredje hovedfunn er knyttet til sammenhengen mellom de tre ulike fasene i refleksjonsprosessen. Det er særlig i informasjonsfasen og det første steget i kunnskapsfasen at lærerne i stor grad utvikler sin forståelse og kunnskap. Denne forståelsen utvikler seg til tross for at lærerne ikke fullt ut utnytter informasjonen om prøveresultatene som ligger i PAS. I stedet synes veiledningen og samtalen å være viktige for utviklingen. Når vi vender oppmerksomheten mot datafasen, ser vi at lærerne stort sett bygger sin forståelse på elevenes mestringsnivå, og at noen er oppmerksomme på mønstre i de ulike dimensjonene ved vokabular i elevresultatene. Likevel ser vi at flere av lærerne ikke henter informasjon fra alle de tre resultatoversiktene. Oversiktene var like 
tilgjengelige i PAS, men det er mulig at den relativt magre utnyttelsen av disse, skyldes at lærerne synes de hadde fått nok informasjon ved å se på fordelingen av mestringsnivå, eller at de andre resultatvisningene ikke opplevdes som nyttige.

Det at lærerne i varierende grad hadde gjort seg kjent med prøveresultatene på itemnivå, kan være en medvirkende årsak til begrenset konkretisering i refleksjonene om tiltak i fremtidig undervisning. Det kan også skyldes at lærerne er usikre på hvordan de kan anvende ny kunnskap til å endre praksis (Datnow \& Hubbart, 2016), og at vi derfor ser eksempler på at ny kunnskap tilpasses eksisterende praksis, for eksempel gjennom reteaching (Datnow et al., 2012; Garner et al., 2017) eller generelle utsagn (Monsen, 2014). Noen av lærernes forslag til endringer i undervisningen var knyttet til undervisningens innhold, for eksempel det å nevne et synonym eller antonym i undervisningen. På den andre siden peker Ingunn, Bente, Anette og Tone på at det må en endring til i hvordan de underviser. Ingunn er den som mest konkret beskriver endringen - det å arbeide med tekster slik veiledningen legger opp til - og hun viser en vending av oppmerksomheten mot hvordan hun kan arbeide med ord som en integrert del av tekstarbeidet. Selv om kunnskapsfasen ikke utnyttes fullt ut, i kraft av konkretiserte tiltak i fremtidig undervisning, er muligheten til stede for at lærernes refleksjonsprosess fortsetter idet de forlater samtalen. Samtalens utvidede kunnskapsgrunnlag har potensial til å vokse og vise seg når den enkelte læreren skal ta fremtidige beslutninger for å støtte sine flerspråklige elevers utvikling av akademisk vokabular i undervisningen.

Endelig finner vi spor av at lærerne i varierende grad retter oppmerksomhet mot flerspråklige elever som gruppe og denne gruppens opplæringsbehov. Under samtalen vender flere av lærerne seg snarere stadig tilbake til å snakke om elever med store vansker, uavhengig av morsmål/førstespråk. Det at lærerne ble overrasket over prøveresultatene til flere av de flerspråklige elevene, kan antyde at lærerne i det daglige er usikre på hvordan de kan vurdere flerspråklige elevers språkkunnskaper og leseforståelse, og at lærernes førforståelse i stor grad styrer deres vurderinger. At mange av elevene kan være $\mathrm{i}$ en andrespråktilegnelsesprosess, synes dermed ikke å være i forgrunn av lærernes bevissthet. Dette peker mot et behov for kompetanseutvikling for lærere når det gjelder elevers andrespråktilegnelse.

\section{IMPLIKASJONER FOR PRAKSIS OG FORSKNING}

Denne artikkelen bidrar med kunnskap som belyser hvilke deler av DDDMprosessen lærerne relativt umiddelbart utvikler kunnskap og forståelse om, og hvilke deler av prosessen som er mer utfordrende. Resultatene tyder på at å analysere prøveresultater på itemnivå, oppleves som fremmed. Å gjøre lærerne mer fortrolige med å undersøke nyansene i disse dataene, slik at de i større grad 
kan oppdage og forankre mønstre på individ- og gruppenivå, er en forutsetning for å utnytte det pedagogiske potensialet i prøvene slik at oppfølgingsarbeidet blir bedre tilpasset den enkelte elevs behov. Når lærerne kommer til det siste steget i kunnskapsfasen, og de der i mindre grad er konkrete, kan det bero på at de i liten grad har benyttet informasjonen som ligger i nyansene i de tre resultatvisningene. Dette er informasjon som trengs i det siste steget på kunnskapsnivået. Utfordringen med å lage vurderingsverktøy som synliggjør hele DDDM-prosessen og som kommuniserer dette godt til lærerne, må prøveutviklere ta med seg videre.

Flyvbjergs (2006) forståelse av det kritiske caset gir innspill til hvordan vi kan forstå studiens funn. Vi har forstått studiens lærere som innehavere av fullt medlemskap i et praksisfellesskap av mellomtrinnlærere, og samtalen som en situasjon hvor mye er lagt til rette for en grundig refleksjonsprosess over de flerspråklige elevenes prøveresultater. Når disse lærerne i denne situasjonen ikke fullt ut utnytter de mulighetene som ligger i prøvekonseptet til å skape anvendbar kunnskap, kan vi anta at andre mellomtrinnlærere i samtaler om prøveresultater som finner sted midt i en travel skolehverdag, også vil møte utfordringer i denne prosessen. Innenfor rammen av studiens samtale ser vi likevel at det er mulig for lærere å utvikle ny forståelse av flerspråklige elevers opplæringsbehov gjennom en strukturert og målrettet samtale om en prøve, elevers prøveresultater og prøvens veiledning. Verdien av at skoler legger til rette for situasjoner hvor lærerfellesskapet kan utvikle ny kunnskap gjennom refleksjon og forhandlinger om praksis, kan derfor være stor. Det krever derimot både tid til gode faglige samtaler i lærerkollegiet, og en struktur for samtalen som peker mot hele DDDM-prosessen hvor også flerspråklige elever blir tematisert.

Studiens avgrensing til én hendelse - samtalen mellom lærerne - gir ikke innsikt i om eller hvordan refleksjonsprosessen fortsetter idet læreren forlater hendelsen, eller i hvordan planene om fremtidig undervisning følges opp. Vi trenger derfor mer kunnskap både om hvordan slike planer følges opp på kort og lang sikt, og mer generelt om hva som skal til for at alle lærere kan utnytte prøveresultater på en slik måte at praksisen imøtekommer alle elevers opplæringsbehov. Samtidig peker studien på et forskningsbehov utover prøvefeltet; når vi ser at lærerne i varierende grad forholder seg til flerspråklige elever som en gruppe, reiser det spørsmål om hvordan de forstår disse elevene, og hvordan de legger til rette for deres opplæringsbehov i undervisningen. 


\section{Om forfatterne}

Hege Rangnes er doktorgradsstipendiat ved Nasjonalt senter for leseopplæring og leseforsking ved Universitet i Stavanger. Hennes forskningsinteresser omfatter blant annet literacy og praksis, muntlighet, lesing 5. - 7. trinn, leseopplæring for flerspråklige elever og pedagogisk bruk av prøver.

Institusjonstilknytning: Nasjonalt senter for leseopplæring og leseforsking ved Universitet i Stavanger, Postboks 8600 Forus, 4036 Stavanger.

E-post: hege.rangnes@uis.no

Aslaug Fodstad Gourvennec er førsteamanuensis ved Nasjonalt senter for leseopplæring og leseforsking ved Universitet i Stavanger. Hennes forskningsinteresser omfatter blant annet litteraturfaglig praksis, litterære samtaler, ferdighetsutøvelse, leseprøver, teknologi i undervisningen, muntlighet og lærersamarbeid.

Institusjonstilknytning: Nasjonalt senter for leseopplæring og leseforsking ved Universitet i Stavanger, Postboks 8600 Forus, 4036 Stavanger.

E-post: aslaug.f.gourvennec@uis.no

\section{Referanser}

Abrams, L. M., McMillan, J. H. \& Wetzel, A. P. (2015). Implementing benchmark testing for formative purposes: Teacher voices about what works. Educational Assessment, Evaluation and Accountability, 27(4), 347-375. https://doi.org/10.1007/s11092-015-9214$\underline{9}$

Ackoff, R. L. (1989). From data to wisdom. Journal of applied systems analysis, 16(1), 3-9.

Anstrom, K., DiCerbo, P., Butler, F., Katz, A., Millet, J., \& Rivera, C. (2010). A review of the literature on academic English: Implications for K-12 English language learners.

Arlington, VA: The George Washington University Center for Equity and Excellence in Education.

Atkinson, J. M. \& Heritage, J. (1999). Transcript notation-structures of social action. Studies in conversation analysis. 13(4-5), 243-249.

Bailey, A. L. \& Butler, F. A. (2003). An evidentiary framework for operationalizing academic language for broad application to K-12 education: A design document. CSE Report. Hentet fra https://cresst.org/wp-content/uploads/R611.pdf

Baker, S., Lesaux, N., Jayanthi, M., Dimino, J., Proctor, C. P., Morris, J., Gersten, R., Haymond, K., Kieffer, M. J., Linan-Thompson, S., \& Newman-Gonchar, R. (2014). Teaching academic content and literacy to English learners in elementary and middle school (NCEE 2014-4012). Washington, DC: National Center for Education Evaluation and Regional Assistance (NCEE), Institute of Education Sciences, U.S. Department of Education. Hentet fra http://ies.ed.gov/ncee/wwc/publications_reviews.aspx.

Barne-, likestillings- og inkluderingsdepartementet. (2012). En helhetlig integreringspolitikk. Mangfold og fellesskap. (Meld. St. 6 2012-2013). Hentet fra https://www.regjeringen.no/no/dokumenter/meld-st-6-20122013/id705945/ 
Breiter, A. \& Light, D. (2006). Data for school improvement: Factors for designing effective information systems to support decision-making in schools. Educational Technology \& society, 9(3), 206-217. Hentet fra http://www.jstor.org/stable/jeductechsoci.9.3.206

Coburn, C. E. \& Turner, E. O. (2011). Research on data use: A framework and analysis. Measurement: Interdisciplinary Research \& Perspective, 9(4), 173206. https://doi.org/10.1080/15366367.2011.626729

Creswell, J. W. (2013). Qualitative inquiry research design: Choosing among five approaches London: Sage.

Datnow, A. \& Hubbard, L. (2016). Teacher capacity for and beliefs about data-driven decision making: A literature review of international research. Journal of Educational Change, 17(1), 7-28. https://doi.org/10.1007/s10833-015-9264-2

Datnow, A., Park, V. \& Kennedy-Lewis, B. (2012). High school teachers' use of data to inform instruction. Journal of Education for Students Placed at Risk (JESPAR), 17(4), 247-265. https://doi.org/10.1080/10824669.2012.718944

Flyvbjerg, B. (2006). Five misunderstandings about case-study research. Qualitative inquiry, 12(2), 219-245. https://doi.org/10.1177/1077800405284363

Gannon-Slater, N., La Londe, P. G., Crenshaw, H. L., Evans, M. E., Greene, J. C. \& Schwandt, T. A. (2017). Advancing equity in accountability and organizational cultures of data use. Journal of Educational Administration, 55(4), 361-

375. https://doi.org/10.1108/JEA-09-2016-0108

Garner, B., Thorne, J. K., \& Horn, I. S. (2017). Teachers interpreting data for instructional decisions: Where does equity come in? Journal of Educational Administration, 55(4), 407-426. https://doi.org/10.1108/JEA-09-2016-0106

Gee, J. P. (2011). An introduction to discourse analysis: Theory and method. London: Routledge.

Golden, A. (2006). Å gripe poenget. Forståelse av metaforiske uttrykk fra lærebøker i samfunnskunnskap hos minoritetselever i ungdomsskolen (Doktorgradsavhandling). Universitetet i Oslo, Oslo.

Golden, A. \& Kulbrandstad, L. I. (2007). Teksten som utgangspunkt for arbeid med lesing og ordforråd: Andrespråksdidaktiske utfordringer i videregående opplæring. NOA: Norsk som andrespråk, 23(2), 33-66.

Gummer, E. \& Mandinach, E. (2015). Building a conceptual framework for data literacy. Teachers College Record, 117(4), 1-22.

Gunnulfsen, A. E. \& Roe, A. (2018). Investigating teachers' and school principals’ enactments of national testing policies: A Norwegian study. Journal of Educational Administration, 56(3), 332-349. https://doi.org/10.1108/JEA-04-2017-0035

Haag, N., Heppt, B., Stanat, P., Kuhl, P. \& Pant, H. A. (2013). Second language learners' performance in mathematics: Disentangling the effects of academic language features. Learning and Instruction, 28, 24-34. https://doi.org/10.1016/j.learninstruc.2013.04.001

Junge, J. (2012). Kjennetegn ved læreres kollegasamtaler, og betydningen av disse for læringspotensialet i samtalene. Norsk pedagogisk tidsskrift, 96(05), 373-386.

Kjærnsli, M. \& Jensen, F. (2016). PISA 2015 - Gjennomføring og noen sentrale resultater. I M. Kjærnsli \& F. Jensen (Red.), Stø kurs. Norske elevers kompetanse i naturfag, matematikk og lesing i PISA 2015. Oslo: Universitetsforlaget.

Kulbrandstad, L. I. (1998). Lesing på et andrespråk: En studie av fire innvandrerungdommers lesing av lareboktekster på norsk (Doktorgradsavhandling). Universitetet i Oslo, Oslo.

Kunnskapsdepartementet. (2013). På rett vei. (Meld. St. 20 2012-2013). Hentet fra https://www.regjeringen.no/no/dokumenter/meld-st-20-20122013/id717308/.

Kvale, S. \& Brinkmann, S. (2015). Det kvalitative forskningsintervju (3 utg.). Oslo: Gyldendal Norsk Forlag AS. 
Lave, J. \& Wenger, E. (1991). Situated learning: Legitimate peripheral participation. Cambridge: Cambridge university press.

Light, D., Wexler, D. \& Heinze, J. (2004, April). How practitioners interpret and link data to instruction: Research findings on New York City Schools' implementation of the Grow Network. Paper presentert på Annual meeting of the American Educational Research Association, San Diego, CA. Hentet fra http://www.cct.edc.org/sites/cct.edc.org/files/publications/Grow_AERA04_fin.pdf

Mandinach, E., Honey, M., Light, D. \& Brunner, C. (2008). A conceptual framework for data-driven decision making. I E. B. Mandinach \& M. Honey (Red.), Data-driven school improvement: Linking data and learning (13-31). New York, NY: Teachers College Press.

Marsh, J. A., Bertrand, M. \& Huguet, A. (2015). Using data to alter instructional practice: The mediating role of coaches and professional learning communities. Teachers College Record, 117(4), 1-40. Hentet

fra https://s3.amazonaws.com/academia.edu.documents/37286377/Marsh_et_al_Mediatin g_TCR.pdf?AWSAccessKeyId=AKIAIWOWYYGZ2Y53UL3A\&Expires=1545127514 \&Signature $=\mathrm{jHiBTlrPAVBaqM} \% 2 \mathrm{BWZDXTktKOnL4 \% 3D \& response-content-}$ disposition=inline\%3B\%20filename\%3DUsing_Data_to_Alter_Instructional_Practi.pdf

Mausethagen, S., Prøitz, T. \& Skedsmo, G. (2018). Teachers' use of knowledge sources in 'result meetings': Thin data and thick data use. Teachers and Teaching. Theory and practice, 24(1), 37-49. https://doi.org/10.1080/13540602.2017.1379986

Maxwell, J. A. (2005). Qualitative research design: An interactive approach (2. utg., vol. 41). Thousand Oaks, Calif: Sage Publications.

Maxwell, J. A. (2008). Designing a qualitative study. The SAGE handbook of applied social research methods, 2, 214-253.

Melby-Lervåg, M. \& Lervåg, A. (2011). Hvilken betydning har morsmålsferdigheter for utviklingen av leseforståelse og dets underliggende komponenter på andrespråket? En oppsummering av empirisk forskning. Norsk pedagogisk tidsskrift, 95(05), 330-343.

Monsen, M. (2014). Store forventninger? Lcreroppfatninger om eksterne leseprøver (Doktorgradsavhandling). Universitetet i Oslo, Oslo.

Nagy, W. \& Townsend, D. (2012). Words as tools: Learning academic vocabulary as language acquisition. Reading Research Quarterly, 47(1), 91-108. https://doi.org/10.1002/RRQ.011

NOU 2010:7. (2010). Mangfold og mestring-Flerspråklige barn, unge og voksne i oppleringssystemet. Hentet fra https://www.regjeringen.no/contentassets/4009862aba8641f2ba6c410a93446d29/no/p dfs/nou201020100007000dddpdfs.pdf

Randen, G. T. (2016). Vurdering av minoritetselevers språkferdigheter i grunnskolen. NOA: Norsk som andrespråk, 31(1-2).

Sandvik-Ebbing, M., Abdalla, W. H. \& Skedsmo, G. L. (2014, 24.-30. juni). Jeg vil bli statsminister! Aftenposten Junior, s. 8-9.

Schildkamp, K. \& Kuiper, W. (2010). Data-informed curriculum reform: Which data, what purposes, and promoting and hindering factors. Teaching and Teacher Education, 26(3), 482-496. https://doi.org/10.1016/j.tate.2009.06.007

Schuth, E., Köhne, J. \& Weinert, S. (2017). The influence of academic vocabulary knowledge on school performance. Learning and Instruction, 49, 157-

165. https://doi.org/10.1016/j.learninstruc.2017.01.005

Seland, I., Vibe, N. \& Hovdhaugen, E. (2013). Evaluering av nasjonale prøver som system (NIFU rapport 4/2013). Hentet fra https://brage.bibsys.no/xmlui/handle/11250/280397 
Snow, C. E. (2010). Academic language and the challenge of reading for learning about science. Science, 328 (5977), 450-452. https://doi.org/10.1126/science.1182597

Strand, O., Wagner, Å. K. H. \& Foldnes, N. (2017). Flerspråklige elevers leseresultater. I E. Gabrielsen (Red.), Klar framgang! (75-95). Oslo: Universitetsforlaget.

Townsend, D., Filippini, A., Collins, P. \& Biancarosa, G. (2012). Evidence for the importance of academic word knowledge for the academic achievement of diverse middle school students. The Elementary School Journal, 112(3), 497518. https://doi.org/10.1086/663301

Utdanningsdirektoratet. (2017). Barn, unge og voksne med innvandrerbakgrunn $i$ grunnopplæringen. Hentet fra https://www.udir.no/tall-og-forskning/finnforskning/rapporter/barn-unge-og-voksne-med-innvandrerbakgrunn-i-grunnopplaringen/.

Vadasy, P. F. \& Nelson, J. R. (2012). Vocabulary instruction for struggling students. New York, NY: Guilford Press.

Wenger, E. (1998). Communities of practice: Learning, meaning, and identity. Cambridge: Cambridge University Press.

Youmans, M. (2013). Fordel å være tokulturell. I M. Youmans (Red.), How to... redde verden og hvor du kan gjøre det (54-57). Oslo: Gyldendal Norsk Forlag AS. 